\title{
Pedestrian Evacuation Time Calculation against Tsunami Hazard for Southern Coasts of Bodrum Peninsula
}

Büşra Çelikbaş ( $\square$ busra.celikbas@metu.edu.tr)

Middle East Technical University: Orta Dogu Teknik Universitesi https://orcid.org/0000-0003-28595184

\section{Duygu Tufekci-Enginar}

Middle East Technical University: Orta Dogu Teknik Universitesi

Gozde Guney Dogan

Middle East Technical University: Orta Dogu Teknik Universitesi

\section{Cagil Kolat}

Middle East Technical University: Orta Dogu Teknik Universitesi

\section{Marzia Santini}

European Commission Joint Research Centre

\section{Alessandro Annunziato}

European Commission Joint Research Centre

\section{Ocal Necmioglu}

Bogazici Universitesi Kandilli Rasathanesi ve Deprem Arastirma Enstitusu

\section{Ahmet Cevdet Yalciner}

Middle East Technical University: Orta Dogu Teknik Universitesi

\section{Mehmet Lutfi Suzen}

Middle East Technical University: Orta Dogu Teknik Universitesi

\section{Research Article}

Keywords: Tsunami evacuation, Least-cost distance (LCD) model, Pedestrian evacuation, Walk time maps, Pedestrian Evacuation Analysis Tool (PEAT)

Posted Date: July 12th, 2021

DOI: https://doi.org/10.21203/rs.3.rs-631820/v1

License: (c) (i) This work is licensed under a Creative Commons Attribution 4.0 International License. Read Full License 


\section{Abstract}

Historical records with recent events reveal that tsunamis are threatening the western coast of Turkey due to intensely active seismicity of the Eastern Mediterranean Sea. The most recent tsunami events in the region (30 October 2020 Izmir-Samos and 20 July 2017 Bodrum-Kos) restated that the cities located near the Eastern Mediterranean and connected seas should consider tsunami events in their disaster mitigation plans. Bodrum is one of the most critical coastal districts, vulnerable to marine hazards with popular hotels, numerous coastal facilities, long and famous beaches, cultural, historical and touristic places. Tsunami evacuation planning is required for Bodrum district to mitigate the damage caused by destructive tsunami waves inundating on land. In this study, the geospatial distribution of pedestrian evacuation time is calculated based on selected credible worst-case scenarios. A widely used anisotropic least-cost-distance (LCD) model is applied via the Pedestrian Evacuation Analyst Tool (PEAT) to calculate the required time for a pedestrian to evacuate the region under tsunami threat based on the selected scenarios. The model includes landscape properties that affect the walking pace of pedestrians during an evacuation, such as elevation, slope, land cover, and land use types (beach, road, bushes, water bodies, any barriers). The resultant pedestrian evacuation time maps show that the maximum time needed for a pedestrian is $8,6,5,4,3$ minutes for highly populated coastal settlements of Bodrum, which are Central Bodrum, Yahsi, Akyarlar-Karaincir-Aspat Bays, Bitez, and Gumbet Bays, respectively.

\section{Introduction}

The world has been witnessing many destructive tsunamis over the past two decades (e.g., 2004 Indian Ocean, 2006 Java, 2007 Solomon Islands, 2009 Samoa, 2010 Chile, 2010 Sumatra, 2011 Tohoku, 2018 Sulawesi), causing a significant amount of life loss worldwide (NGDC 2012). Although those catastrophic tsunamis mostly occurred in the Pacific Ocean, historical records reveal that the coast of Turkey experienced destructive tsunamis in its past (Ambraseys 1962; Soloviev et al. 2000; Fokaefs and Papadopoulos 2007; Ambraseys and Synolakis 2010; Altınok et al. 2011; Papadopoulos et al. 2012). There are various hazard assessment analyses conducted to model the typical tsunamigenic sources based on the historical reports on the western coast of Turkey (Altinok et al. 2011; Salamon et al. 2007; Yolsal et al. 2007; Lorito et al. 2008; Yalciner et al. 2008; Okal et al. 2009; Basili et al. 2013; Sørensen et al. 2012; Papadopoulos et al. 2014). According to the seismic mechanisms of Hellenic and Cyprus arcs in the Eastern Mediterranean Sea, Yolsal et al. (2007) interpreted the tsunamigenic hazard zones in the region. Lorito et al. (2008) portrayed the large set of seismic tsunamis generated by major fault zones in the Mediterranean Sea and concluded that not only distant but also local sources are needed to understand source-impact zones. Seismic tsunami sources that could create tsunami hazards in the Mediterranean and in the Aegean Sea are also investigated by Yalciner et al. (2008). Okal et al. (2009) modelled the 1956 Amorgos tsunami triggered by an earthquake associated with extensional tectonics in the back arc region of Hellenic subduction. According to the eyewitness reports, they concluded that observed tsunami is incompatible with only seismic source and demonstrated both seismic and landslide source models. Basili et al. (2013) concluded the impact of tsunamis generated by Mw $=7$ earthquakes 
are expected to be strong at many localities in Eastern Mediterranean Sea depend on parametric fault characterization in terms of geometry, kinematics and activity rates. Papadopoulos et al. (2014) provided tsunami hazard zones in the Mediterranean Sea and its connected seas based on various sources, including historical documents, geological signs, geomorphological imprints, observations from selected coastal sites, instrumental records and eyewitnesses. Necmioglu and Ozel (2015) presented a comprehensive earthquake-generated tsunami hazard analysis for the Eastern Mediterranean, Aegean and Black Seas through a large tsunami scenario database composed of 2415 scenarios. In addition to those studies displaying the possible tsunami source zones in the Mediterranean Sea, two recent tsunami events striking the coasts of Turkey and Greece, Bodrum-Kos (20 July 2017, 20:31 UTC) and Izmir-Samos (30 October 2020, 12:51 UTC), have indicated once more that both countries should also be prepared against tsunami hazard and mitigate the resultant damage and casualties (Dogan et al. 2019 and Dogan et al. 2021). Therefore, recently, emergency managers, planners, and local decision-makers seek mitigation strategies against destructive tsunami waves. Educating at-risk populations about what to do during a possible tsunami event and how to be prepared for such an event plays a vital role in tsunami risk reduction (NRC 2011). Especially for the sudden onset hazards like nearshore tsunamis, increasing awareness and evacuation planning is becoming the primary way to save lives as evacuees have a few minutes to escape from the inundated zone towards the safety zone (NTHMP 2001). Therefore, it is essential to estimate if the at-risk communities would have enough time for evacuation. Developing optimal evacuation planning is a critical phenomenon for emergency managers and planners to assess the risk more accurately and realistically for vulnerable coastal communities that will become more resilient (González-Riancho et al. 2013; Wang et al. 2016, Tufekci et al. 2021).

There have been several studies in literature, focusing on understanding whether or not at-risk populations have sufficient time to evacuate from hazard zone before the arrival of the first tsunami wave (Laghi and Cavalletti 2004; Jonkmann et al. 2008; Graehl 2009; Post et al. 2009; Yeh et al. 2009; Mas et al. 2012; Lovholt et al. 2012; Wood and Schmidtlein 2012, 2013; Fraser et al. 2014; Wang et al. 2016; Wang and Jia 2021). In recent years, dynamic models (simulations, Agent-Based Models (ABM)) and static algorithms (shortest and quickest path, minimum cost network flow, Least-Cost Distance (LCD) models) have been used to model tsunami evacuation (Cheff et al. 2018). All available models make some assumptions generalizing information about individuals, landscape properties, or creating a hazard zone; therefore, an ideal evacuation model applicable to all individuals ceases to exist.

ABMs are dynamic models that simulate the individual behavior and their interaction during an evacuation from a specific tsunami scenario according to user-defined rules via mathematical equations and statistical analyses (Mas et al. 2012). Instead of a specific scenario, evacuation maps should reflect a credible worst-case scenario (Walsh et al. 2000) or maximum hazard zone that summarizes multiple scenarios (Suleimani et al. 2002, 2010; Wilson et al. 2008; Nicolsky et al. 2011, 2013). Furthermore, estimating human behavior during an evacuation, the primary goal of $A B M s$ is a highly complex issue that may change depending on the community's preparedness and education level. Due to coastal populations' spatial and temporal variability, emergency managers mostly require evacuation time information independent of population exposure and used in general education and preparedness 
planning (Wood and Schmidtlein 2012). Instead of dynamic properties, LCD models calculate the shortest path for an evacuee to reach a safe zone from every location in a hazard zone via Geographic Information System (GIS) based on the static landscape properties (e.g., slope, land cover, road network) (Wood and Schmidtlein 2012).

In literature, LCD approaches to model pedestrian evacuation have become a growing topic (Laghi et al. 2006; Graehl 2009; Post et al. 2009; Wood and Schmidtlein 2012, 2013; and Fraser et al. 2014). LCD models examine pedestrian evacuation in various ways, from simple models based on the only distance to safety from hazard zone to more complex models, including the landscape properties (e.g., slope, landcover, land-use, transportation network) affecting the walking pace of pedestrian. Post et al. (2009) increased LCD models' complexity by including population density in the travel costs and considering the required time from the beginning of the tsunami warning sign. Lately, studies focused on calculating travel costs, including the properties blocking the pedestrian evacuation to the LCD model, such as natural and structural barriers (e.g., rivers and fences), buildings, lakes, or high slopes. Travel costs might be calculated by either cost-distance algorithms (isotropic cost distance) or path distance algorithms (anisotropic cost distance). Cost-distance algorithms calculate the straight distance between every cell in the hazard zone to the safety, whereas path distance ones (anisotropic cost distance) calculate actual, trigonometric distances between various elevation points. Wood and Schmidtlein (2012) made a sensitivity analysis of LCD models to elevation and landcover data, where they concluded that anisotropic cost distance models estimate travel times more realistic than isotropic ones. Lately, anisotropic LCD models have been preferred to calculate evacuation times by path distance algorithms for self-initiated pedestrian evacuation from sudden onset-hazards such as tsunamis, debris flows, volcanic mudflows, and flash floods (Wood and Schmidtlein 2012, 2013 and Fraser et al. 2014).

Therefore, this study focuses on the spatial distribution of evacuation times via the LCD approach rather than understanding individual behavior and attractions during an evacuation. The research is also interested in understanding the difficulties of movement across the landscape during the evacuation rather than individual behavior and interaction during an evacuation. In this approach, real-world evacuation conditions like landscape characteristics that affect pedestrian movement were also taken into account. The results also reveal whether individuals within the danger zone (hazard zone-inundated or flooded area) could evacuate before tsunami waves arrive on the land, which provides valuable information for local emergency managers.

This study aims to prepare pedestrian tsunami evacuation time maps for the southern coasts of the Bodrum peninsula, to be used as a base map for emergency managers and local decision-makers during emergency planning. In coherence with this scope, to estimate spatial evacuation time distribution within the hazard zone anisotropic LCD modeling via PEAT (Jones et al. 2014) is calculated and verified at the field.

The study is a part of the Last Mile project which was conceived and organized by the JRC with funding from the European Commission department for civil protection and humanitarian aid operations (DG 
$\mathrm{ECHO}$ ). The project was conducted by the joint team at the Remote Sensing and GIS Laboratory in the Department of Geological Engineering and Coastal and Ocean Engineering Division in the Department of Civil Engineering of Middle East Technical University.

The Tsunami modelling part of the project is presented in Dogan et al. (202X), where, five seismic (365Crete, 1303-Eastern Mediterranean, 1956-Amorgos, Gokova and Gulluk Bay), two submarine landslides (Amorgos and Gokova-North-Datca), and two earthquake-triggered submarine landslide scenarios are defined. The numerical modelling results indicate that among the five seismic scenarios 1956-Amorgos seismic scenario gives the maximum inundation distances and flow depth values through Bodrum Marina, Gumbet Bay, Bitez Bay, Yahsi Bay, and Turgutreis regions. On the other hand, among combined and landslide scenarios, the combined Gokova seismic and North Datca landslide scenario gives the highest water levels at many locations along the southern coast of Bodrum (Dogan et al. 202X). In this study, the resultant 1956-Amorgos seismic and combine Gokova seismic and North Datca landslide scenarios are used in the creation of a hazard zone for PEAT and named as Scenario A and B, respectively.

\section{Study Area}

The study area for the tsunami evacuation model is the southern coast of Bodrum Peninsula (Fig. 1). Bodrum is a district of Muğla province, located in the southwest of the Aegean Region of Turkey and coasts to the eastern Mediterranean Sea, a worldwide touristic center, hosting popular hotels with long and famous beaches, historical and touristic places. The population is 181.541 (TUIK 2020), which increases to more than a million during the summer months as its economic livelihood is mainly tourism (Erdogan 2016).

The Mediterranean Sea hosts active faults and zones that can create many earthquakes and tsunamis (Lorito et al. 2008, Tiryakioğlu et al. 2018). Bodrum Peninsula lies on the Northern side of the Gulf of Gokova, a seismically active region of the Alpine-Himalayan belt, formed by the North-South-directed extensional regime of Western Anatolia (Dewey and Şengor 1979). Bodrum Peninsula and Gulf of Gokova region are the most seismically active areas of western Turkey, where earthquake swarms occurred (Kalafat and Horasan 2012). Gokova Fault Zone, which is the most active fault in Southwest Anatolia where the epicenters of earthquakes are concentrated, is extended to the north of the gulf and separated into several second-order submarine faults (Tiryakioğlu et al. 2018). Ocakoğlu et al. (2018) founded a good correlation between the region's general seismicity and the focal mechanism solutions of the 20 July 2017 Bodrum-Kos earthquake. The earthquake generated a tsunami affecting the southern coasts of the Bodrum Peninsula with a maximum runup of $1.9 \mathrm{~m}$ (Dogan et al. 2019).

\section{Pedestrian Evacuation Modeling Via Peat}

The time required for a pedestrian to reach out of hazard zone is based on an LCD model implemented in GIS software of ESRI's ArcMap (Wood and Schmidtlein 2012, 2013; Jones et al. 2014). The Pedestrian 
Evacuation Analyst Tool (PEAT) used in this study considers the difficulties of pedestrian movement within a hazard zone (cost-distance) based on the static landscape properties such as slope and landcover types. PEAT was developed by Jones et al. (2014) with the USGS support as a decision support system for studies on self-initiated pedestrian evacuation against the sudden onset hazards like tsunamis, lahars, flash floods. It calculates required evacuation time by considering an anisotropic path distance model where the difficulty of the direction of travel against a slope is incorporated. However, PEAT does not take into account possible crowd behavior, such as panic and chaos, which may have an effect on the time required for evacuation. The anisotropic LCD model uses cost-distance geoprocessing that also includes the influence of land cover types (Laghi et al. 2006, Post et al. 2009). Land cover and elevation-derived slope data are converted to speed conservation values (SCVs), representing maximum travel speeds expected on areas with given conditions (Wood and Schmidtlein 2012). The generation of evacuation time maps in PEAT requires two main processes: preprocessing input data (DEM, landuse/land-cover, hazard zone, and safe zone) and creating respective evacuation surfaces (Jones et al. 2014).

\subsection{Preprocessing of data}

\subsubsection{Digital Elevation Model (DEM)}

In the first stage of PEAT, high-resolution DEM and derivatives (slope map) of Bodrum Peninsula are used (Fig. 2). Since the search direction of the Path Distance Tool of PEAT is opposite of the direction of evacuation, downhill in the algorithm means uphill for an evacuee. The slope direction is inverted since the LCD calculations of PEAT begin from the safety and expand towards the hazard zone. Various researchers had used different slope-walking speed relationships in literature (Butler et al. 2000; Post et al. 2009; Graehl, 2009; Anguelova et al. 2010). In this study, SCVs are based on Tobler's (1993) hiking function, which explains the relation between topographic slope values and walking speed of a pedestrian (Wood and Schmidtlein 2012).

\subsubsection{Land-cover/Land-use}

The required land cover/land use dataset (roads, rivers, etc.) used in PEAT is provided by Bodrum Municipality within the scope of the Last Mile project (Necmioğlu et al. 2019). In addition, open-source data of Open Street Map and Google Earth Images are used for the cases that require modifications due to inconsistency or deficiency of the provided data.

Land-cover/Land-use data is composed of a base and ancillary layer to satisfy PEAT requirements. The base layer represents the spatial distribution of Earth's coverage of study areas, affecting pedestrians' walking pace during an evacuation, such as beaches, cultivated lands, and bushes, created from Google Earth Images due to the absence of available data. Several studies have been conducted to classify landcover layers into SCV surfaces (Laghi et al. 2006; Post et al. 2009; Anguelova et al. 2010). However, in this study, SCVs of each land-cover type are formed with the information provided by Wood and Schmidtlein 
(2012). Once a composite land cover vector data is created, SCVs are assigned to each type of data (Table 1) based on the energy cost terrain coefficients defined by Soule and Goldman (1972). Among all the land cover types, developed highly-populated areas provide the pedestrian an easy way for vertical and horizontal evacuation due to the proximity to buildings and roads; hence its SCV has the highest value of 0.9091 . On the other hand, coastal areas like Bodrum having large and populated beaches with unconsolidated sand where it is hard to walk has the lowest SCV (0.5556). Cultivated crops and bushes are the landcover types where walking through them for evacuation is more convenient than beaches; therefore, 0.8333 is assigned.

In addition to the base layer, any layer that makes pedestrian evacuation easier, harder, or blocking is considered as an ancillary layer such as roads, fences, buildings, water bodies (Wood and Schmidtlein 2012). Roads are the primary pathways for pedestrians to evacuate in the easiest and fastest way, whereas, any water body can abruptly block the evacuation (such as rivers, lakes), of which both are included as ancillary layers (Fig. 3). Therefore, SCV varies from 0 , meaning no evacuation possible like rivers, to 1 , such as roads providing the most suitable surface for pedestrians (Table 1). The SCV will then be used as a source to create the cost-inverse raster of different land-cover types in PEAT (Table 1).

Table 1

Speed conservation values of the land-cover types (Wood and Schmidtlein 2012)

\begin{tabular}{|ll|}
\hline Land-cover Type & Speed Conservation Value (SCV) \\
\hline Road & 1 \\
\hline Developed- highly populated & 0.9091 \\
\hline Cultivated crops & 0.8333 \\
\hline Bush & 0.8333 \\
\hline Beach & 0.5556 \\
\hline Rivers & 0 \\
\hline
\end{tabular}

\subsubsection{Hazard zone/Safe zone}

Hazard zones are defined as inundated areas on land from the credible worst-case scenarios (Dogan et al. 202X), Scenario B creates the maximum inundation area for Central Bodrum, Gumbet Bay, Yahsi Bay, and Akyarlar-Karaincir-Aspat Bays (Fig. 4a,b,c and d). As an exception, both scenarios give high inundation levels through different places in Bitez Bay (Fig. 4e). Therefore, for Bitez Bay, the A and B scenarios are merged to define the cumulative hazard zone. PEAT uses resultant hazard zones as input to create a safety zone for pedestrians to evacuate. The raster flow depth results of numerical modelling is vectorized and validations of safe zones are done by removing excessive sliver polygons and safe zone islands within the inundated hazard zones.

\subsection{Resultant evacuation walk time surfaces}


The path distance surface is generated using the Path Distance Geoprocessing Tool (ESRI 2009) that calculates the cost-distance according to elevation and land-cover/land-use SCVs. Evacuation time surface is calculated by dividing path-distance surface with recommended walking speed of evacuee assigned according to crosswalk walking standards in the United States as a slow walking pace $(1.1 \mathrm{~m} / \mathrm{s})$ (Wood and Schmidtlein 2012). Therefore, most LCD studies suggested a slow walk speed of evacuees for the mixed population (age, health, gender, physical mobility, etc.) (Wood and Schmidtlein 2012, 2013; Wood and Peters 2015).

The evacuation time maps are produced for selected five areas, Central Bodrum, Gumbet, Yahsi, and Akyarlar-Karaincir-Aspat and Bitez Bays, based on critical scenarios A and B (Fig. 5). The resultant evacuation time maps show the time zones for evacuees with a 1-minute increment except for the first increment ( 0.5 minutes). As a result of our study, the longest time required for evacuees to get out of hazard zone with $1.1 \mathrm{~m} / \mathrm{s}$ walking speed from the tip of Bodrum Marina's breakwater is calculated as 8 minutes (Fig. 5a). However, in the absence of breakwater, the travel time is calculated as 4 minutes from the Aganlar Shipyard \& Marina. As it is expected, famous beaches located at the Bodrum like Gumbet Beach (3 minutes), Camel Beach (6 minutes) located in Yahsi Bay, Aspat Beach (5 minutes), Karaincir Municipal Beach ( 5 minutes) have the longest evacuation time since they are the places having maximum inundation distances (Fig. 5b-d). Those areas have high tourist flow, especially in the summer seasons, and the highest travel time to reach the safe boundary. In addition to beaches, the tsunami waves easily inundate through valleys also; hence the longest time required for a pedestrian is calculated as 5 minutes around the valley entrance located in Bitez Bay (Fig. 5e). The study areas are dominated by rivers that mostly pour into the sea through beaches. Therefore, those beaches face greater danger because tsunami waves inundate faster through valleys.

\section{Discussion}

Successful evacuation planning is critical for emergency managers and local decision-makers to save lives from potential future tsunamis. As in all evacuation models, there is no way to create ideal evacuation planning; hence some assumptions have to be made according to the applied model. In this section, the assumptions that are made through this study is discussed.

Tsunami numerical simulations are performed according to the present mean sea level; however, it continuously changes due to tides or storms, hence for different seasons, lunar cycles, sea level fluctuations and climatic changes a sensitivity analysis should be made followed by a multitemporal evacuation analysis.

The inundation is assumed as composed of only water, not the debris material, during the numerical simulations. However, the damage is mostly due to the debris materials carried by tsunami waves, such as boats, cars, parts of trees, and concrete particles detached from the ground or houses.

In an actual tsunami event, the arrival of the first wave to the land differs, but it is assumed for LCD models that all locations are inundated simultaneously. Therefore, in some places, there may be more time for individuals to initiate an evacuation. 
According to the resultant evacuation walk time maps (Fig. 5), it seems like there is enough time for individuals to reach safety from the shortest route with slow walking speed since the arrival of the first tsunami wave is higher than the calculated evacuation time required. However, the tsunami warning system's reaction time, including the institutional notification and the decision time to notify the at-risk community (Post et al. 2009), is also neglected since there is no effective tsunami warning system in the study area currently, despite a pilot local tsunami early warning system has been deployed as part of the Last Mile (Necmioglu et al. 2019) project and being tested. In addition to the delay in the tsunami warning process, the different evacuation behavior depending on individual awareness is not included in the LCD model. Furthermore, the effect of possible crowd behavior, such as panic and chaos, has not been taken into consideration (Liu et al. 2018).

The earthquake's impact on buildings, roads, bridges, or any structure is neglected, which may slow the evacuation dramatically, or even preclude at certain evacuation routes. Additionally, all the buildings are assumed as reinforced concrete and not damaged by the tsunami waves. However, in coastal resorts like Bodrum, there are lots of unstructured temporal buildings, shelters, etc., that are vulnerable to earthquakes and tsunami waves. In the case of a strong earthquake, reinforced concrete buildings may collapse along with unstructured ones towards the important roads, which leads to block the evacuation suddenly and cause congestion. In PEAT, roads are assumed as the safest places to evacuate for an individual. However, in addition to the collapse of buildings, the road network may be destroyed by an earthquake due to liquefaction.

The routes in docks and breakwaters are where evacuations are difficult since there is only one narrow path to reach the safe zone (Wood and Peters 2015). Although it does not reflect the reality, it is assumed that all the roads have identical SCVs providing the easiest way for a pedestrian.

In this study, we implemented the LCD model instead of ABMs to understand the spatial distribution of the required evacuation time for a pedestrian based on landscape properties. The LCD models ignore the individual behavior and interactions during an evacuation. In contrast, ABMs assess hundreds of individuals' decisions and their interactions based on a set of rules (Wang et al. 2016). Understanding and modeling individual decision-making behavior during a panic situation like evacuation is a very complex phenomenon, which depends on the different awareness of all individuals affected by near experiences and ancestral knowledge of that region (Tufekci et al. 2021). In addition to that, LCD models ignore congestion of roads leading to panic among evacuees that causes prolonged the required evacuation time. Depending on the roads' congestion level, evacuees' travel speed may vary; however, in LCD models, it is assumed that all individuals in a community have the same and constant speed of evacuation (Wood and Schmidtlein 2012). There is no information on the human capacity in the available road dataset, which is essential to prevent congestions during an evacuation. It is vital knowledge for emergency managers and local decision-makers to offer the routes in evacuation planning. 
PEAT requires lots of complex data representing landscape properties that affect pedestrians' walking pace during an evacuation, such as slope, barriers, roads, or water bodies located within the hazard zone (Wood and Schmidtlein 2013). In order to create successful evacuation planning, the data must be accurate, up-to-date, and with high resolution. In this study, the available data is provided by Bodrum Municipality and open sources like Google Earth Images and Open Street Map. Since the shoreline of Bodrum is continually changing and developing due to the construction of new coastal facilities such as marinas, renewed buildings, constructions of new buildings like hotels and roads, the data used for the LCD models should be updated regularly to avoid misleading an evacuee. In addition to that, resultant evacuation time maps (Fig. 5) are sensitive to the assumptions made in the land-cover and slope SCVs (Schmidtlein and Wood 2015). Due to the lack of available data in this study, land-cover data are produced from Google Earth Images, which is user-dependent. The created land-cover data are classified, and SCVs are given according to Wood and Schmidtlein (2012).

Bodrum is one of Turkey's largest holiday towns and also attracts many tourists from abroad; hence the population rises to $\sim 2$ million people in the summer seasons (Erdogan 2016). The spatial distribution of the population is time-depended and changes dramatically based on seasons in holiday towns. Since the occurrence time of a tsunami cannot be estimated, the detailed dataset that should represent the spatial distribution of population both in summer and winter seasons should be included in the evacuation plans. In addition to seasonal changes, even both day and night population continuously changes. No such data represents all population variability; hence, in the study, the population is ignored.

Furthermore, evacuation is assumed to performed only horizontally; vertical evacuation to the buildings is ignored. Likewise, multi-evacuation is not allowed in the model, only self-initiated pedestrian evacuation is permitted as it is the most useful way for sudden hazards like tsunami, debris flow, etc.

\subsection{Validation of resultant evacuation time surfaces}

The resolution of input data for PEAT totally affects the interpretation of resultant tsunami evacuation maps (Fig. 5) by an individual during an evacuation. According to the model sensitivity analysis conducted by Wood and Schmidtlein (2012), PEAT tended to underestimate the required evacuation time with coarser-resolution elevation data. Therefore, DEM resolution plays a critical role in the resultant maps and validation is required to make sure accuracy of resultant evacuation time maps (Fig. 5). For this purpose, four different locations having maximum evacuation time to reach the safe zone and their shortest path to reach the safe zone are selected as validation routes (Fig. 6-9). While choosing the validation road, it was prioritized that the road was wide and the fastest for pedestrians. The validation is performed by a nearly constant speed not exceeding $1.1 \mathrm{~m} / \mathrm{s}$. During the walk, actual time and distances are recorded (Table 2). The time calculated by PEAT in the final resultant evacuation time maps at the locations where the validation route starts (Fig. 6-9) is compared with the time passed to reach the safe zone during the walk (Table 2). 
According to validation results (Table 2), the measured time to reach the safe zone from selected validation routes is lower than it is calculated by PEAT. Therefore, for those three routes (Fig. 6, 7, and 9), evacuation is possible with $1.1 \mathrm{~m} / \mathrm{s}$ speed according to the proposed evacuation time of PEAT. However, in the case of the Bitez-2 validation route (Fig. 8), field experts thought that the selected route was within the hazard zone and walked $40 \mathrm{~m}$ more than it is calculated by PEAT for that route even there is no panic situation during validation. As shown in Fig. 8, there is a valley where the hazard zone continues $40 \mathrm{~m}$ more right next to the validation route. Increasing the accuracy and decreasing the misinterpretation and confusion of evacuees depends on using detailed and high-resolution data.

Table 2

Measurements during the walk on validation routes

\begin{tabular}{|lllll|}
\hline $\begin{array}{l}\text { Validation } \\
\text { Route }\end{array}$ & $\begin{array}{l}\text { Evacuation Time from PEAT } \\
\text { Results (min) }\end{array}$ & $\begin{array}{l}\text { Measured } \\
\text { Distance }(\mathrm{m})\end{array}$ & $\begin{array}{l}\text { Measured } \\
\text { Time } \\
(\mathbf{m i n})\end{array}$ & $\begin{array}{l}\text { Average Speed } \\
(\mathbf{m} / \mathbf{s})\end{array}$ \\
\hline Gumbet & 3 & 124 & 2.32 & 0.82 \\
\hline Bitez-1 & 4 & 171 & 2.52 & 0.99 \\
\hline Bitez-2 & 5 & 356 & 5.35 & 1.06 \\
\hline Yahsi & 6 & 361 & 5.35 & 1.08 \\
\hline
\end{tabular}

\section{Conclusion}

The necessary base study on tsunami evacuation modeling is conducted for emergency managers and local decision-makers. The geospatial distribution of pedestrian evacuation time was calculated via PEAT (Jones et al. 2014), one of the LCD models, for highly populated coastal areas of Bodrum Peninsula; Central Bodrum, Gumbet Bay, Bitez, Bay, Yahsi Bay, and Akyarlar-Karaincir-Aspat Bays. The hazard zones used in PEAT is obtained from resultant worst-case scenarios of the study where the numerical simulations performed via the NAMI DANCE model (Dogan et al. 202X). The tool considers the SCVs representing the relationship between walking speed and landscape properties such as slope and landcover/land-use. In this study, a slow walk walking speed $(1.1 \mathrm{~m} / \mathrm{s})$ is taken in the calculations.

The final resultant maps reveal the spatial distribution of time required for a person to reach a safe zone in the fast and easiest way. According to evacuation walk time maps (Fig. 5), the longest evacuation times are 8, 6, 5, 4, and 3 minutes for Central Bodrum, Yahsi, Akyarlar-Karaincir-Aspat Bays, Bitez, and Gumbet bays, respectively. Furthermore, the maps were validated via fieldwork on four selected different routes by performing on foot evacuation with a constant desired speed.

\section{Declarations}

\section{Acknowledgements}


This study was partly supported by Turkey Tsunami Last Mile Project Analyses JRC/IPR/2018/E.1/0013/NC with contract number 936314-IPR-2018. The data used in this study were either provided by Bodrum Municipality or acquired from open sources (Google Earth Images and Open Street Maps). We would like to thank Doğan Kalafat, Gülüm Tanırcan and Siret Bali for their cooperation and vast contribution to the work.

\section{Funding}

Partial financial support was received from Turkey Tsunami Last Mile Project Analyses JRC/IPR/2018/E.1/0013/NC with contract number 936314-IPR-2018.

\section{Conflicts of interest/Competing interests}

The authors have no conflicts of interest to declare that are relevant to the content of this article.

\section{Availability of data and material}

The data used in this study is provided by Bodrum Municipality and acquired from open sources (Google Earth Images and Open Street Maps).

\section{Code availability}

Pedestrian Evacuation Analyst Tool, developed by USGS for ArcGIS 10.5, is used in the study during calculations. (available at; https://www.usgs.gov/software/pedestrian-evacuation-analyst-tool)

\section{References}

1. Altınok Y, Alpar B, Özer N and Aykurt H (2011) Revision of the Tsunami Catalogue Affecting Turkish Coasts and Surrounding Regions. Natural hazards Earth System Science, 11, 273-293

2. Ambraseys N (1962) Data for the investigation of the seismic sea-waves in the Eastern Mediterranean. Bulletin of the Seismological Society of America, 52(4), 895-913

3. Ambraseys N, \& Synolakis C (2010) Tsunami catalogs for the Eastern Mediterranean, revisited. Journal of Earthquake Engineering, 14(3), 309-330

4. Anguelova Z, Stow DA, Kaiser J, Dennison P.E., Cova T. (2010) Integrating fire behavior and pedestrian mobility models to assess potential risk to humans from wildfires within the U.S.-Mexico border zone. Prof Geogr 62(2):230-247

5. Basili R, Tiberti MM, Kastelic V, Romano F, Piatanesi A, Selva J, \& Lorito S (2013) Integrating geologic fault data into tsunami hazard studies. Natural Hazards and Earth System Sciences, 13(4), 10251050. https://doi.org/10.5194/nhess-13-1025-2013

6. Butler B, Cohen J, Putnam T, Bartlette R, Bradshaw L (2000) A method for evaluating the effectiveness of firefighter escape routes. In: Proceedings of the 2000 international wildfire safety summit, pp 42-53 
7. Cheff I, Nistor I, Palermo D (2018) Pedestrian evacuation modelling of a Canadian West Coast community from a near-field tsunami event. Nat. Hazards https://doi.org/ 10.1007/s11069-0183487-5

8. Dewey JF, Şengör AMC, (1979) Aegean and surrounding regions. Complex multiplate and continuum tectonics in a convergent zone. Geol. Soc. Am. Bull. 90, 84-92

9. Dogan GG, Annunziato A, Papadopoulos GA, Guler HG, Yalciner AC, Cakir TE, Sozdinler CO, Ulutas E, Arikawa T, Suzen ML, Guler I, Probst P, Kanoglu U, Synolakis C (2019) The 20th July 2017 BodrumKos Tsunami Field Survey. Pure Appl. Geophys., 176: 2925

10. Dogan GG, Yalciner AC, Yuksel Y, Ulutaş E, Polat O \& Kanoğlu U (2021) The 30 October 2020 Aegean Sea Tsunami: Post-Event Field Survey Along Turkish Coast. Pure Appl. Geophys. https://doi.org/10.1007/s00024-021-02693-3

11. Dogan GG, Necmioglu O, Tufekci-Enginar D, Kalafat D, Annunziato A, Santini M, Yalciner B, Tanircan G, Suzen ML, Yalciner AC (202X) Worst-Case Scenario-Based Tsunami Hazard Analysis of Bodrum Peninsula by High-Resolution Numerical Modeling (in Review)

12. Erdogan G (2016) Fractal Dimension Of Urban Pattern: Bodrum, Turkey. 23rd International Seminar on Urban Form (ISUF)At: Nanjing, China

13. ESRI (2009) Path distance: adding more cost complexity. Available at http://webhelp.esri.com/ arcgisdesktop/9.3/index.cfm?TopicName=Path_Distance:_adding_more_cost_complexity. Accessed 16 July 2010

14. Fokaefs A and Papadopoulos AG (2007) Tsunami Hazard in the Eastern Mediterranean: Strong Earthquakes and Tsunamis in Cyprus and the Levantine Sea. Natural Hazards, 40,503-526

15. Fraser S, Wood N, Johnston D, Leonard G, Greening P, Rossetto T (2014) Variable population exposure and distributed travel speeds in least-cost tsunami evacuation modelling. Nat. Hazards Earth Syst. Sci. 14 2975-2991

16. González-Riancho P, Aguirre-Ayerbe I, Aniel-Quiroga I, Abad S, González M, Larreynaga J, Gavidia F, Gutiérrez OQ, Álvarez-Gómez JA, and Medina R (2013) Tsunami evacuation modelling as a tool for risk reduction: application to the coastal area of El Salvador. Nat. Hazards Earth Syst. Sci., 13, 32493270, doi:10.5194/nhess-13-3249-2013

17. Graehl N (2009) Using a GIS to model pedestrian evacuation times for Newport, OR. Unpublished research, Humbolt State University, California

18. Jones JM, Ng P, Wood, NJ (2014) The pedestrian evacuation analyst-Geographic information systems software for modeling hazard evacuation potential: U.S. Geological Survey Techniques and Methods, book 11, chap. C9, 25 p., https://dx.doi.org/10.3133/tm11C9

19. Jonkmann S, Vrijling J, Vrouwenvelder A (2008) Methods for the estimation of loss of life due to floods: a literature review and a proposal for a new method. Nat Hazards 46:353-389

20. Kalafat D and Horasan G (2012) A seismological view to Gokova region at southwestern Turkey. International Journal of Physical Sciences, 7(30), 5143-5153 
21. Laghi M and Cavalletti A (2004) Coastal Risk Analysis of Tsunamis and Environmental Remediation. Evacuation Routes Tools ArcGIS toolbox. Retrieved 1 February, 2008, from the following web site: www.adpc.net/v2007/IKM/ONLINE\%20DOCUMENTS/Default-DOCUMENTS.asp

22. Laghi M, Polo P, Cavalletti A and Gonella M (2006) G.I.S. Applications for Evaluation and Management of Evacuation Plans in Tsunami Risk Areas. European Geosciences Union General Assembly 2007, Vienna, Austria.

23. Lorito S, Tiberti MM, Basili R, Piatanesi A and Valensise G (2008) Earthquake-generated tsunamis in the Mediterranean Sea: scenarios of potential threats to Southern Italy, Journal of Geophysical Research, Vol. 113, B01301, doi: 10.1029/2007JB004943.

24. Lovholt F, Setiadi NJ, Birkmann J, Harbitz CB, Bach C, Fernando N, Nadim F (2012) Tsunami risk reduction - are we better prepared today than in 2004? International Journal of Disaster Risk Reduction, 10, 127-142. doi:10.1016/j.ijdrr.2014.07.008

25. Liu T, Liu Z, Ma M, Chen T, Liu C, \& Chai Y (2018) 3D visual simulation of individual and crowd behavior in earthquake evacuation. SIMULATION, 95(1), 65-81. https://doi.org/10.1177/0037549717753294

26. Mas E, Suppasri A, Imamura F, \& Koshimura S (2012) Agent-based Simulation of the 2011 Great East Japan Earthquake/Tsunami Evacuation: An Integrated Model of Tsunami Inundation and Evacuation. Journal of Natural Disaster Science, 34(1), 41-57. doi:10.2328/jnds.34.41

27. National Geophysical Data Center/World Data Service (NGDC/WDS) (2012) Global historical tsunami database. National Geophysical Data Center, NOAA. Available from http://www.ngdc.noaa.gov/hazard/tsu_db.shtml

28. National Research Council (NRC) (2011) Tsunami warning and preparedness: an assessment of the US tsunami program and the nation's preparedness efforts. Committee on the Review of the Tsunami Warning and 300 Nat Hazards (2012) 62:275-300

29. Necmioglu $O$ and Ozel NM (2015) Earthquake Scenario-Based Tsunami Wave Heights in the Eastern Mediterranean and Connected Seas. Pure and Applied Geophysics, 172(12), 3617-3638

30. Necmioğlu Ö, Yalciner AC, Kalafat D, Süzen ML, Tanırcan G, Annunziato A, Santini M, Doğan GG, Tufekci-Enginar D, Güneş Y, Yelkenci Necmioğlu S, Bali S, Özener H (2019) Addressing Challenges and Requirements for Local Tsunami Awareness, Warning And Mitigation: A "Last Mile" Case Study For Bodrum-Turkey, at 5. International Conference on Earthquake Engineering and Seismology (5thICEES 8-11 October 2019, METU ANKARA TURKEY)

31. Nicolsky D, Suleimani E, Combellick R, Hansen R (2011) Tsunami inundation maps of Whittier and western Passage Canal, Alaska. Alaska Division of Geological \& Geophysical Surveys Report of Investigation 2011-7, $65 \mathrm{p}$

32. Nicolsky D, Suleimani E, Haeussler P, Ryan H, Koehler R, Combellick R, Hansen R (2013) Tsunami inundation maps of Port Valdez, Alaska. Alaska Division of Geological \& Geophysical Surveys Report of Investigation 2013-1, 77 p, 1 sheet, scale 1:12,500 
33. NTHMP (2001) Designing for Tsunami - Seven Principles for Planning and Designing for Tsunami Hazards. National Tsunami Hazard Mitigation Program. USA, NOAA, USGS, FEMA, NSF, Alaska, California, Hawaii, Oregon, and Washington

34. Ocakoğlu N, Nomikou P, Isçan Y, Loreto MF, Lampridou D (2018) Evidence of extensional and strikeslip deformation in the offshore Gökova-Kos area affected by the July 2017 Mw6.6 Bodrum-Kos earthquake, eastern Aegean Sea. Geo-Marine Letters

35. Okal EA, Synolakis CE, Uslu B, Kalligeris N, \& Voukouvalas E (2009) The 1956 earthquake and tsunami in Amorgos, Greece. Geophysical Journal International, 178(3), 1533-1554

36. Papadopoulos GA, Minoura K, Imamura F, Kuran U, Yalciner AC, Fokaefs A, Takahashi T (2012) Geological evidence of tsunamis and earthquakes at the Eastern Hellenic Arc: correlation with historical seismicity in the eastern Mediterranean Sea. Research in Geophysics 2012; volume 2:e12, pp: $90-99$

37. Papadopoulos GA, Gràcia E, Urgeles R, Sallares V, De Martini PM, Pantosti D, \& Papageorgiou A (2014) Historical and pre-historical tsunamis in the Mediterranean and its connected seas: Geological signatures, generation mechanisms and coastal impacts. Marine Geology, 354, 81-109

38. Post J, Wegscheider S, Muck M, Zosseder K, Kiefl R, Steinmetz T, Strunz G (2009) Assessment of human immediate response capability related to tsunami threats in Indonesia at a sub-national scale. Nat Hazards Earth Syst Sci 9:1075-1086

39. Schmidtlein, MC, Wood NJ (2015) Sensitivity of tsunami evacuation modeling to direction and land cover assumptions. Applied Geography, 56, 154-163. https://doi.org/10.1016/j.apgeog.2014.11.014

40. Salamon A, Rockwell T, Ward SN, Guidoboni E, \& Comastri A (2007) Tsunami hazard evaluation of the eastern Mediterranean: historical analysis and selected modeling. Bulletin of the Seismological Society of America, 97(3), 705-724

41. Soloviev SL, Solovieva ON, Go CN, Kim KS and Shchetnikov NA (Eds.) (2000) Tsunamis in the Mediterranean Sea - 2000 B.C.-2000 A.D., Kluwer Academic Publishers, 237 pp

42. Soule RG, and Goldman RF (1972) Terrain coefficients for energy cost prediction. Journal of Applied Physiology, v. 32, no. 5, p. 706-708

43. Sørensen MB, Spada M, Babeyko A, Wiemer S, \& Grünthal G (2012) Probabilistic tsunami hazard in the Mediterranean Sea. Journal of Geophysical Research: Solid Earth, 117(B1)

44. Suleimani E, Hansen R, Combellick R, Carver G (2002) Tsunami hazard maps of the Kodiak area, Alaska. Alaska Division of Geological \& Geophysical Surveys Report of Investigation 2002-1, 16 p, 4 sheets, scale 1:12,500

45. Suleimani E, Nicolsky D, West D, Combellick R, Hansen R (2010) Tsunami inundation maps of Seward and northern Resurrection Bay, Alaska. Alaska Division of Geological \& Geophysical Surveys Report of Investigation 2010-1, 47 p, 3 sheets, scale 1:12,500

46. Tiryakioğlu B, Aktuğ C, Yiğit Ö, Yavaşoğlu H, Sözbilir H, Özkaymak Ç, Poyraz F, Taneli E, Bulut F, Doğru A \& Özener H (2018) Slip distribution and source parameters of the 20 July 2017 Bodrum-Kos 
earthquake (Mw6.6) from GPS observations. Geodinamica Acta, 30:1, 1-14, DOI: 10.1080/09853111.2017.1408264

47. Tobler W (1993) Three presentations on geographical analysis and modeling-non-isotropic geographic modeling. Speculations on the geometry of geography; and global spatial analysis. UCSB. National Center for Geographic Information and Analysis Technical Report 93-1

48. Tufekci-Enginar D, Suzen ML, \& Yalciner AC (2021) The evaluation of public awareness and community preparedness parameter in GIS-based spatial tsunami human vulnerability assessment (MeTHuVA). Natural Hazards. doi:10.1007/s11069-020-04416-8

49. TUIK (2020) Turkish Statistical Instıtute. http://www.tuik.gov.tr

50. Walsh T, Caruthers C, Heinitz A, Myers III E, Baptista A, Erdakos G, Kamphaus R (2000) Tsunami hazard map of the southern Washington coast-modeled tsunami inundation from a Cascadia subduction zone earthquake. Washington Department of Natural Resources Division of Geology and Earth Resources Geologic Map GM-49

51. Wang H, Mostafizi A, Cramer LA, Cox D, \& Park H (2016) An agent-based model of a multimodal nearfield tsunami evacuation: Decision-making and life safety. Transportation Research Part C: Emerging Technologies, 64, 86-100. doi:10.1016/j.trc.2015.11.010

52. Wang Z, \& Jia G (2021) A novel agent-based model for tsunami evacuation simulation and risk assessment. Natural Hazards, 105(2), 2045-2071. doi:10.1007/s11069-020-04389-8

53. Wilson R, Barberopoulou A, Miller K, Goltz J, Synolakis C (2008) New maximum tsunami inundation maps for use by local emergency planners in the State of California. USA: EOS, Transactions of the American Geophysical Union, v. 89, no. 53, Fall Meeting Supplement, Abstract OS43D-1343

54. Wood NJ, \& Peters J (2015) Variations in population vulnerability to tectonic and Landslide-related tsunami hazards in Alaska. Natural Hazards, 75(2), 1811-1831. doi:10.1007/s11069-014-1399-6

55. Wood NJ, and Schmidtlein MC (2012) Anisotropic path modeling to assess pedestrian-evacuation potential from Cascadia-related tsunamis in the US Pacific Northwest: Natural Hazards, v. 62, no. 2, p. 275-300, doi 10.1007/ s11069-011-9994-2

56. Wood NJ, \& Schmidtlein MC (2013). Community variations in population exposure to near-field tsunami hazards as a function of pedestrian travel time to safety. Natural Hazards, 65(3), 16031628. doi:10.1007/s11069-012-0434-8

57. Yalciner AC, Dilmen ID, Insel I (2008) An Investigation on the Tsunami Risk Map of Turkey. Report of the Project ODTÜ, 06-03-03-2-02-05, for Ministry of Transport Turkey

58. Yeh H, Fiez T, Karon J (2009) A comprehensive tsunami simulator for Long Beach Peninsula phase-1 framework development final report. State of Washington Military Department Emergency Management Division

59. Yolsal S, Taymaz T, \& Yalciner AC (2007). Understanding tsunamis, potential source regions and tsunami-prone mechanisms in the Eastern Mediterranean. Geological Society, London, Special Publications, 291(1), 201-230 


\section{Figures}
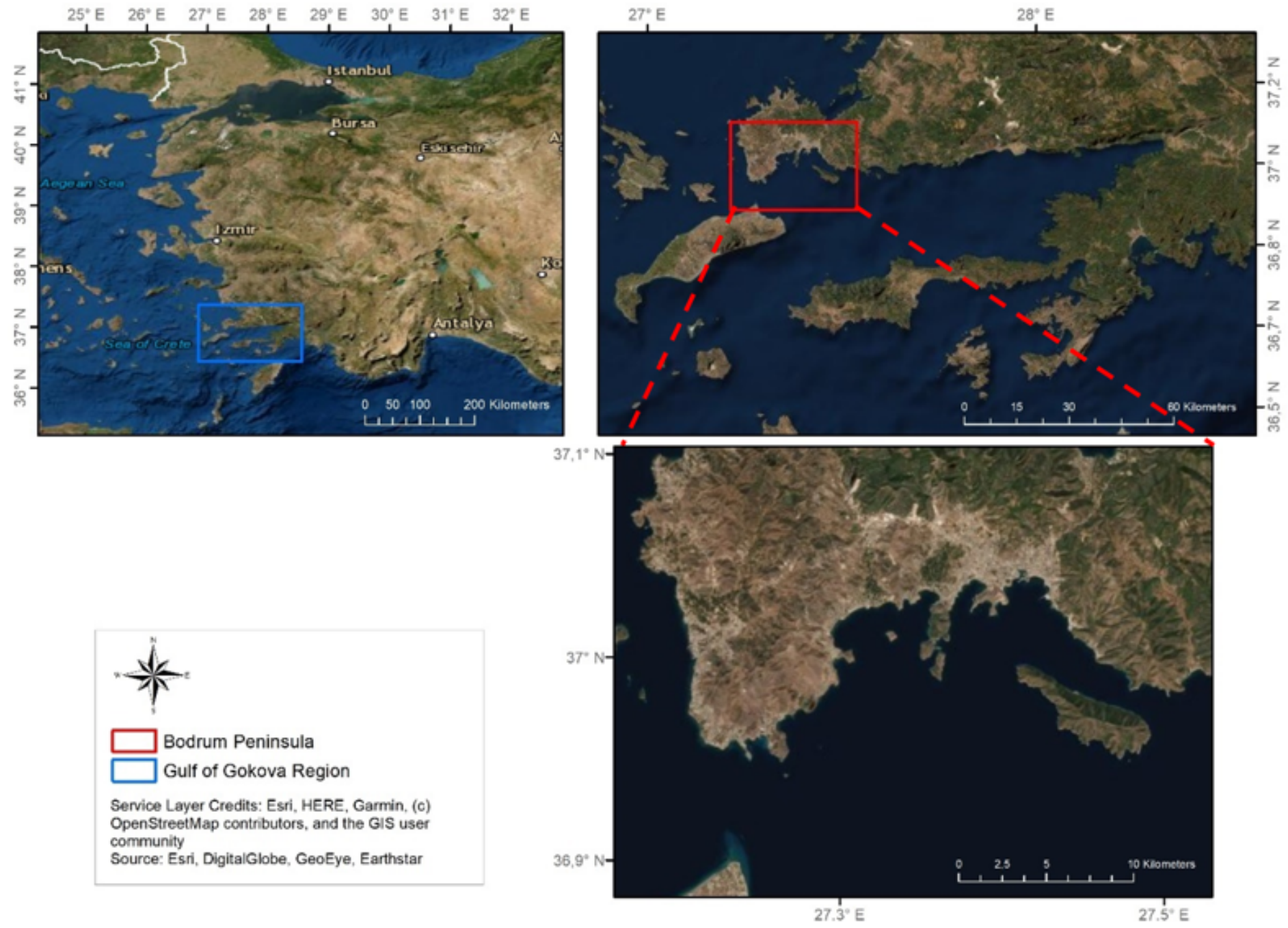

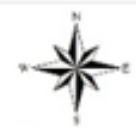

Bodrum Peninsula Gulf of Gokova Region

Service Layer Credits: Esri, HERE, Garmin, (c) OpenStreetMap contributors, and the GIS user community

Source: Esri, DigitalGlobe, GeoEye, Earthstar

Figure 1

Location of Bodrum Peninsula 


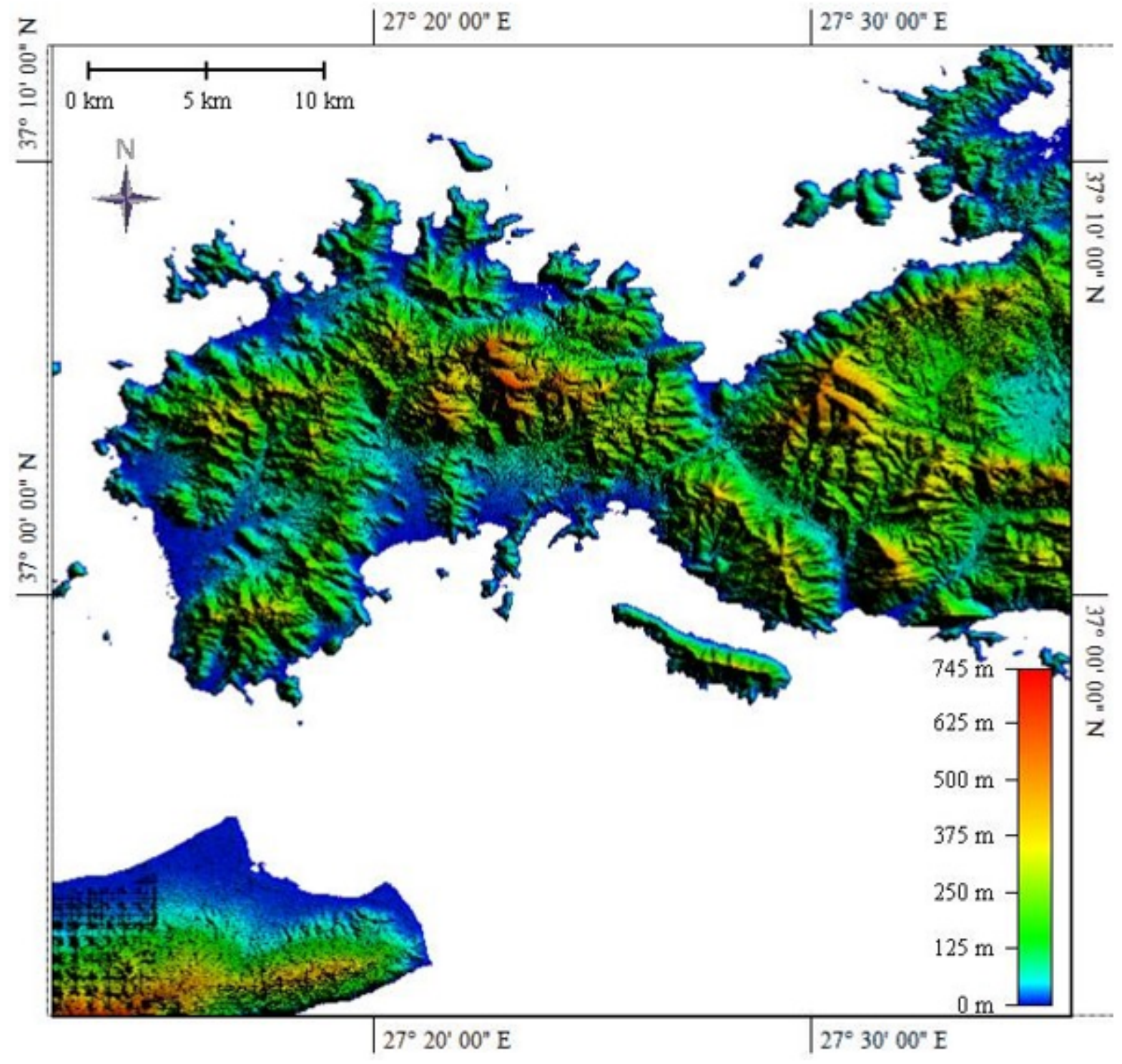

Figure 2

Digital Elevation Model (DEM) used in PEAT 

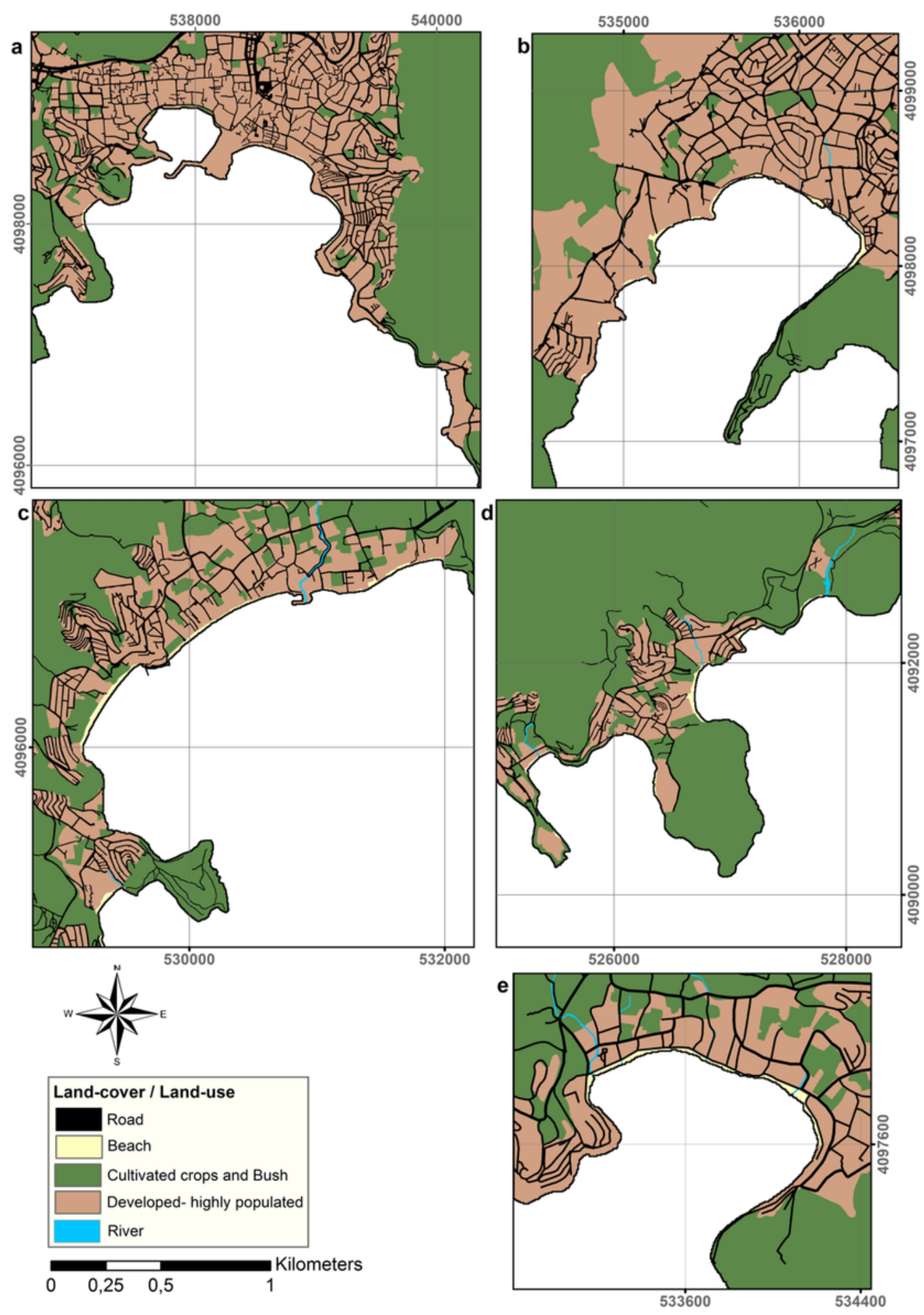

\section{Figure 3}

The land-cover/Land-use map composed of beaches, cultivated crops, bushes, and additional road and river ancillary layers for a. Central Bodrum, b. Gumbet Bay, c. Yahsi Bay, d. Akyarlar-Karaincir-Aspat Bays, e. Bitez Bay 

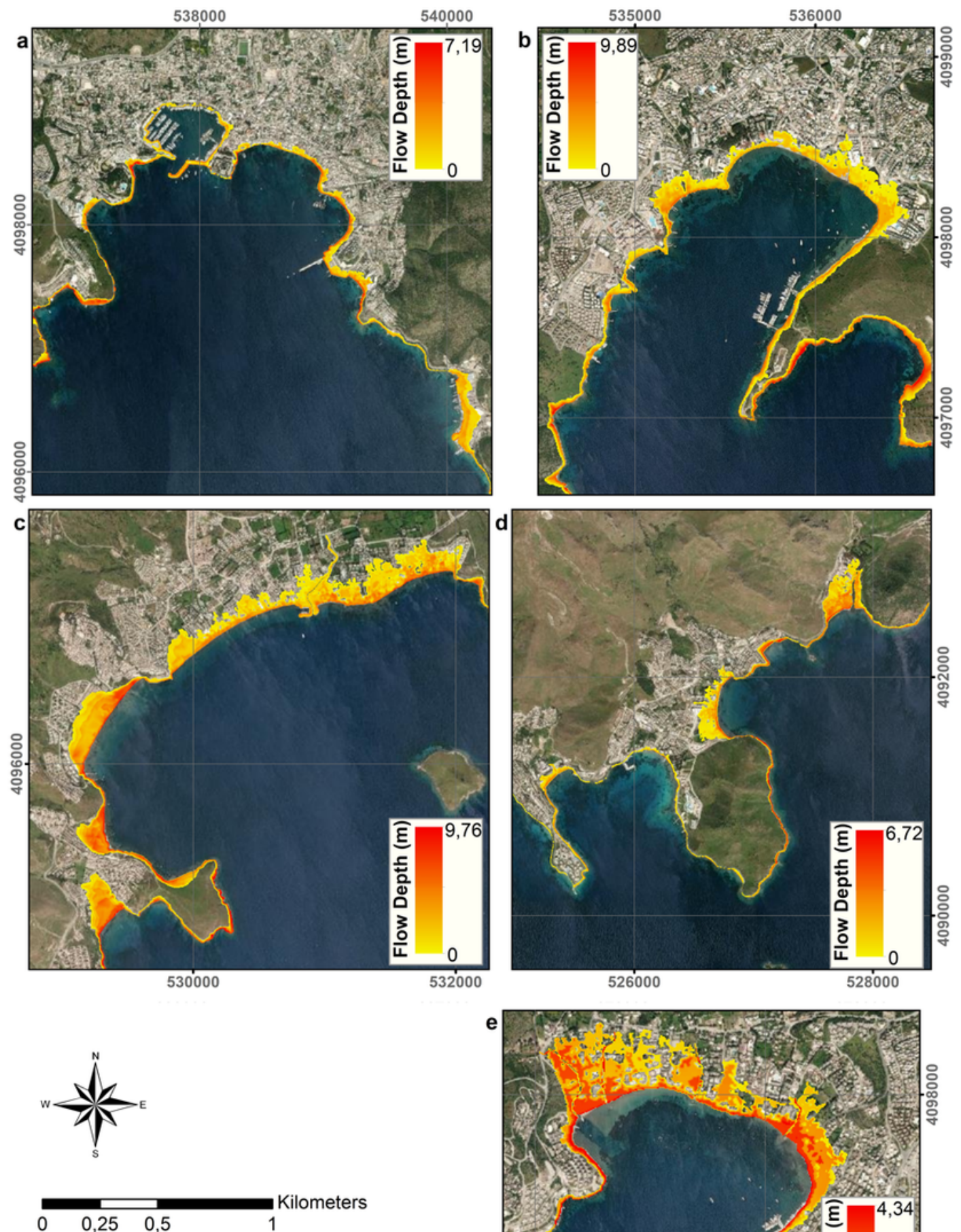

Service Layer Credits: Source: Esri,

DigitalGlobe, GeoEye, Earthstar Geographics, CNES/Airbus DS, USDA, USGS, AeroGRID, IGN, and the GIS User Community

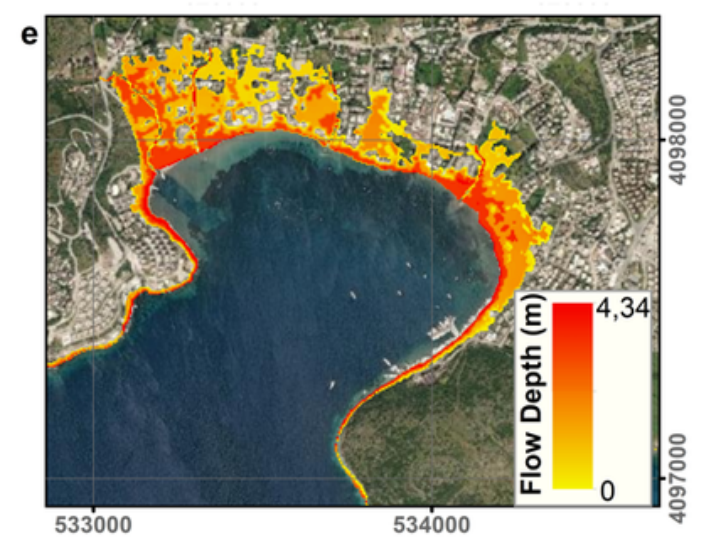

\section{Figure 4}

Flow depth maps used as hazard inputs for PEAT (Dogan et al. 202x). a. Central Bodrum, b. Gumbet Bay, c. Yahsi Bay, d. Akyarlar-Karaincir-Aspat Bays, e. Bitez Bay 

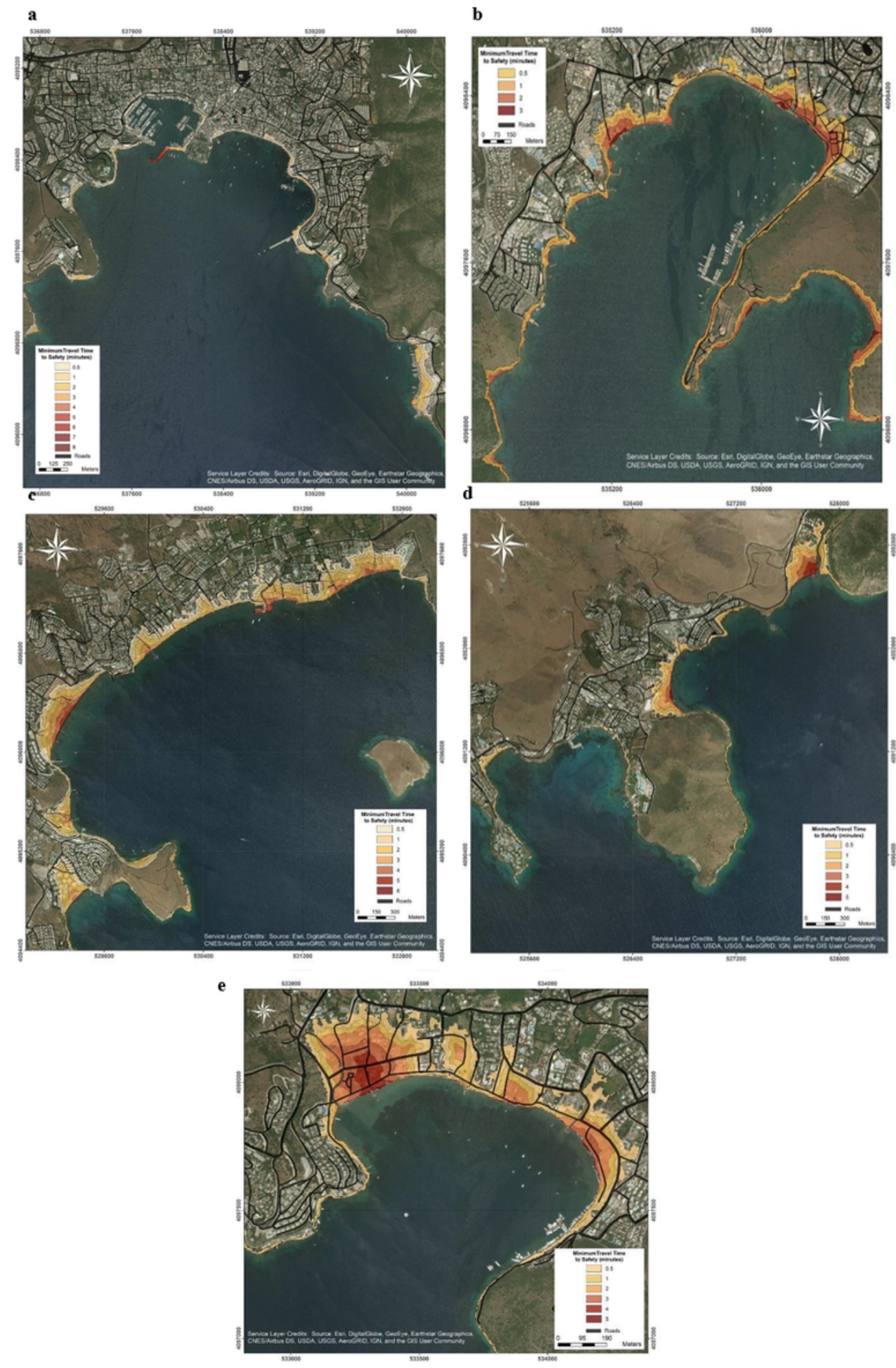

\section{Figure 5}

Tsunami Evacuation Walk Time Map for a. Central Bodrum, b. Gumbet Bay, c. Yahsi Bay, d. AkyarlarKaraincir-Aspat Bays, e. Bitez Bay 

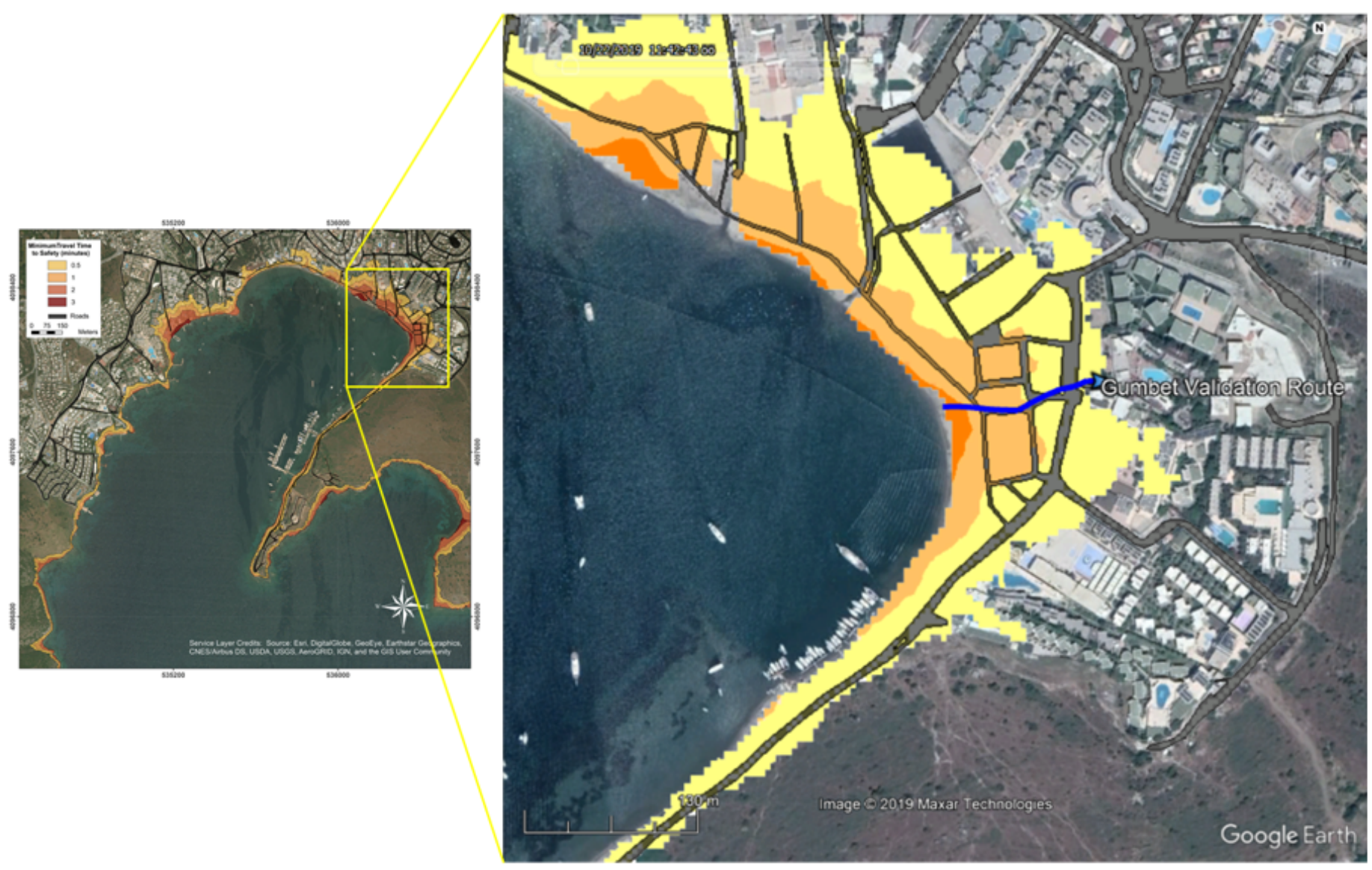

Figure 6

Validation route in Gumbet Bay shown as blue line 

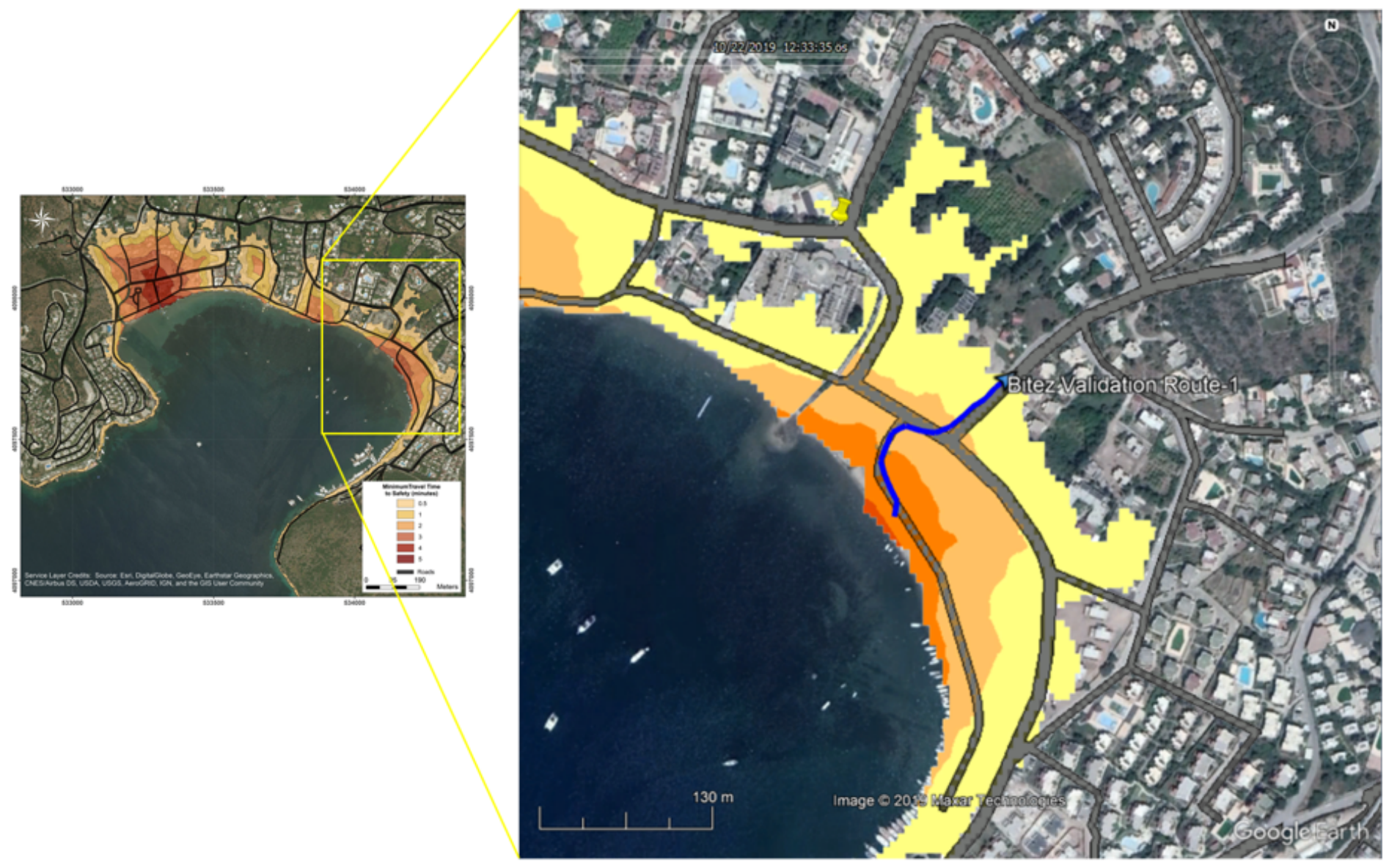

Figure 7

Validation route of Bitez-1 shown as blue line 


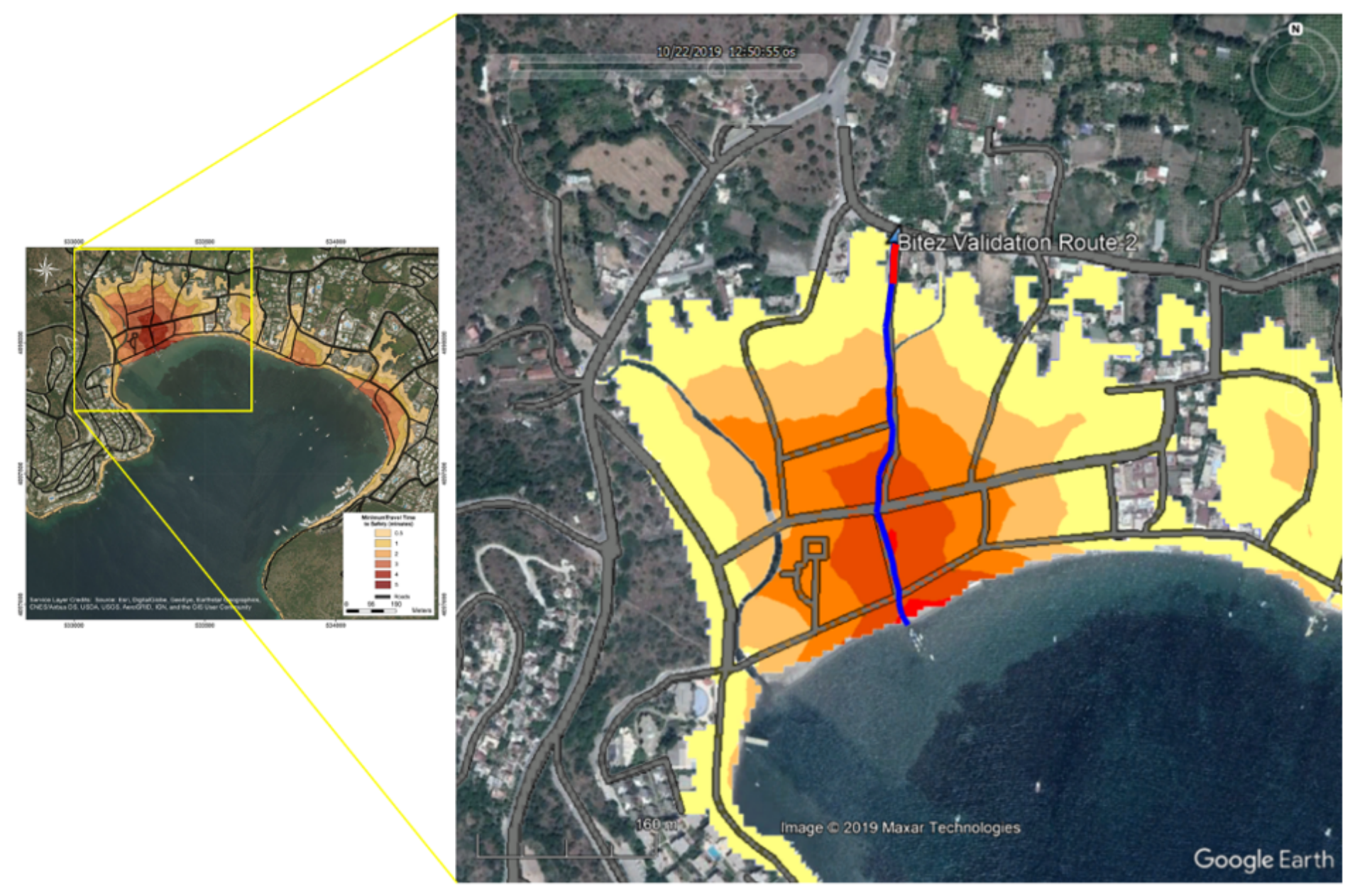

Figure 8

Validation route of Bitez-2 shown as blue line, overwalking shown as red line 


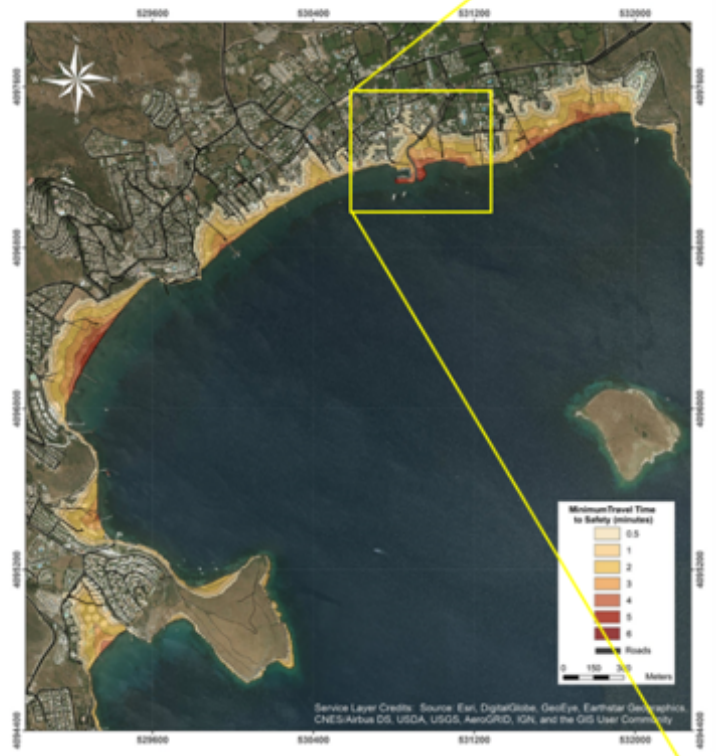

\section{Figure 9}

Validation route in Yahsi Bay shown as blue line

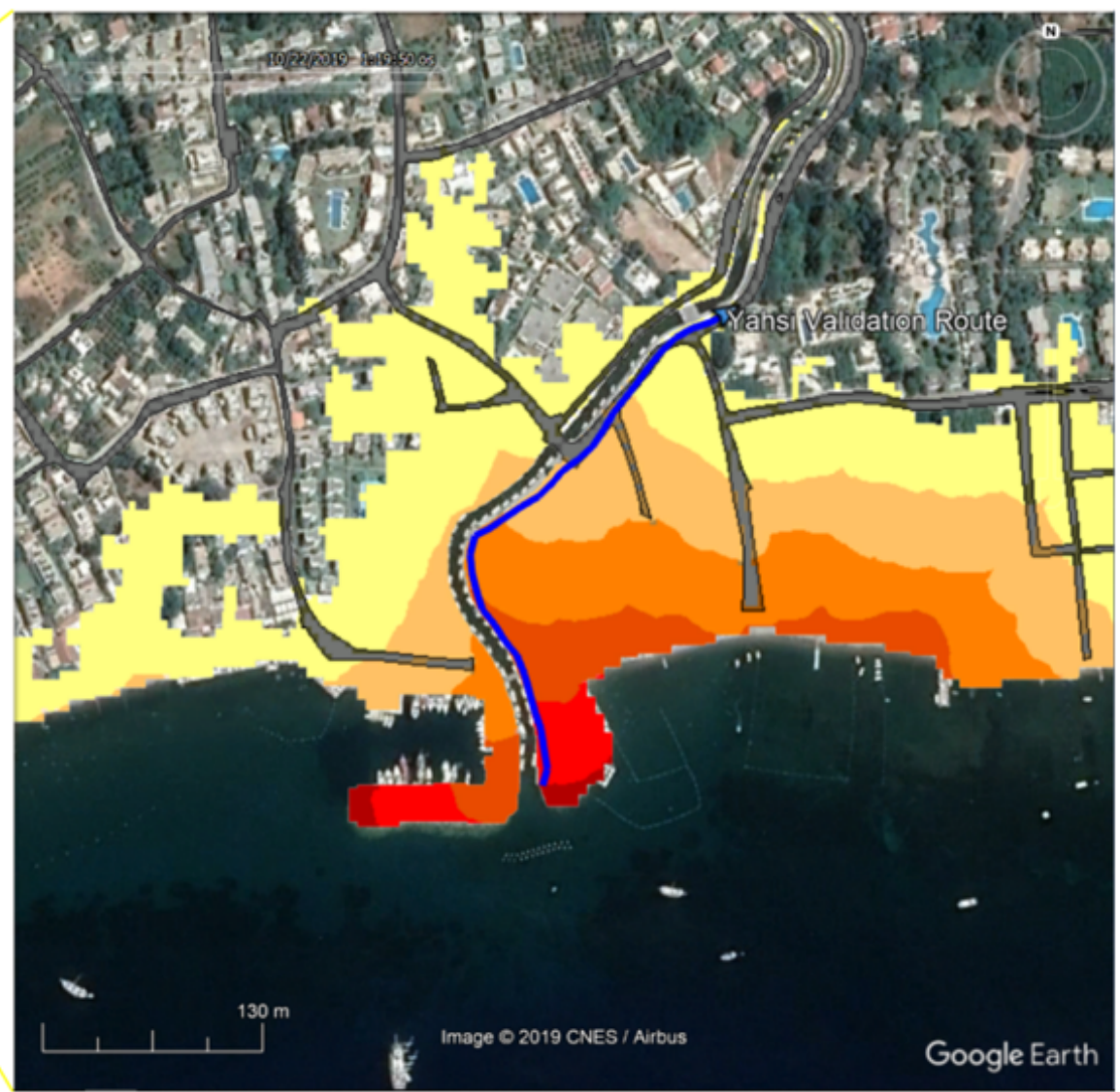

Google Earth 